\title{
The Efficiency of Using Different Mulch Films in the Cultivation of Yellow Gentian (Gentiana lutea L.) in Serbia
}

\author{
Dragoja Radanović ${ }^{1}$ Tatjana Marković J Jovica Vasin $^{2} \cdot$ Dušana Banjac $^{2}$ \\ ${ }^{1}$ Institute for Medicinal Plant Research „Dr Josif Pančić”, Tadeuša Košćuška 1, 11000 Belgrade, Serbia \\ Institute of Field and Vegetable Crops, Maksima Gorkog 30, 21000 Novi Sad, Serbia
}

\begin{abstract}
Summary: Field trial with yellow gentian was established (11.1 plants per $\left.\mathrm{m}^{2}\right)$ at $1004 \mathrm{~m}$.a.s.l., in order to assess the effect of black PE (bPE), silver PE (sPE), and black permeable biodegradable (bPB) mulching films on the root yield and development during six years. The highest crop density measured prior to the root harvest (sixth year), was obtained in the plot with bPB film (84\%), while in the plot with bPE and in control (without mulch) number of plants was reduced by $34.2 \%$ and $45 \%$, respectively. In addition, application of the bPB film proved to be the most effective treatment; in the fifth and sixth year root yields per $\mathrm{m}^{2}$ increased by $92.3 \%$ and $106.0 \%$, respectively, in comparison to bPE, and by $78.9 \%$ and $69.2 \%$, respectively, in comparison to sPE, and by $184.4 \%$ and $169.6 \%$, respectively, in comparison to control. Application of bPE had a lower positive effect on YG root yield than control $(-18.6 \%-54.95 \%)$, whereas the effect of sPE was higher than the bPE and control; the achieved root yields were higher, $29.7 \%$ and $70.6 \%$, respectively.

Key words: films, Gentiana lutea, root yield, mulches, yellow gentian
\end{abstract}

\section{Introduction}

Yellow gentian (Gentiana lutea L.) belongs to the family Gentianaceae and is a medicinal plant widespread throughout Europe, endangered in its natural habitat in many countries due to overexploitation. Moreover, the interest in its cultivation is increasing in many countries due to a large quantity of the standard quality root (Gentianae radix) used in the production of bitter spirits, food and pharmaceutical industry (Seitz et al. 2005).

Although the research on yellow gentian cultivation in Europe started over four decades ago, its successful cultivation is still a great challenge for producers (Franz 2012). Cultivation lasts for 4-6 years and its success depends on numerous factors. In south and southeast Europe it can be successfully grown only in regions over 1000 m.a.s.l. (Bezzi \& Aiello 1993, Radanović et al. 2014), which often lack the working-age population and machinery for high quality soil tillage, rely on traditional extensive farming principles, and have very little experience in applying modern cultivation practices.

Application of mulch films in weed control is most common in flat lowland areas of Serbia, where it is

Corresponding author:

dradanovic@mocbilja.rs

Acknowledgements:

This study was conducted under the project TR31072 "Status, trends and possibilities to increase the fertility of agricultural land in the Vojvodina Province", and the project III 46008 "The development of integrated systems of managing harmful organisms in order to overcome resistance and improve food quality and safety", both supported by the Ministry of Education, Science and Technological Development of Republic of Serbia. mostly used in the production of vegetables, berries, and watermelons. There is no experience in Serbia regarding production of yellow gentian with the use of black PE mulch films, whereas such experience with favourable results exists in the environmental conditions of Finland (Galambosi 1996). Weed control in cultivated yellow gentian is a great organisational problem and a significant cost for producers in Serbia. Besides the labour shortage in mountainous regions, producers frequently face extreme weather (drought, high summer temperatures or heavy rainfall) which disturb in time cultivation practice - tillage and weeding, and cause an unsatisfactory outcome of the production.

Besides the positive effects on weed control, the use of mulch films also improves soil moisture management and significantly affects the soil temperature regime (Momirović et al. 2010). This study aimed to test the efficiency of different mulch films on the development of yellow gentian plants and root yields grown under the agroecological conditions of mountainous regions in western Serbia.

\section{Materials and Methods}

\section{Locality}

The experiment was conducted at the locality Kaluđerske Bare (1004 m.a.s.l., latitude 43 53'42" N and longitude $19^{\circ} 33^{\prime} 15^{\prime \prime} \mathrm{E}$ ) of the Tara Mountain in Serbia. Mountain Tara is situated in the region with the highest precipitation in Serbia (multi-year average is $1000 \mathrm{~mm}$ per year), with predominantly continental pattern, reaching its maximum in May and June and 
minimum in February or October. Average annual air temperature in mountainous regions of southwest Serbia (above 1000 m.a.s.l.) is approximately $6^{\circ} \mathrm{C}$. The coldest month is January, with average monthly temperatures about $-6^{\circ} \mathrm{C}$, and the warmest is July with average temperatures ranging between $11-16^{\circ} \mathrm{C}$ (RHMZ 2015).

\section{Field experiment set up}

Experiments were set up in September 2005. Yellow gentian seedlings were planted in open beds, which were $1.2 \mathrm{~m}$ wide and $10 \mathrm{~m}$ long, and set to be $1 \mathrm{~m}$ apart from each other. Seedlings were planted in open beds using the spacing of $30 \times 30 \mathrm{~cm}$, with the crop density of 11.1 plants per $\mathrm{m}^{2}$. Prior to planting, the beds were covered with 3 different mulch films: black polyethylene (PE) film (bPE), silver polyethylene film (sPE), and black permeable biodegradable (bPB) mulching films. Identical open bed was used as control without the use of mulch films. Annual gentian seedlings, produced at the same locality in containers $500 \mathrm{ml}$ in volume, were used for planting.

During the first two seasons, irrigation was applied with the use of two drip tapes only under PE mulch films, while the plants grown under permeable mulch film and control were not irrigated. Weeds were not removed in any variants during the entire course of the experiment.

Mineral fertilizer NPK 8:26:26 (600 kg/ha) was applied by soil tilling during bed preparation. The experiment was conducted in four replications. At the end of each season, following the roots extraction from the $1.1 \mathrm{~m}^{2}$ surface of the open bed $(0.9 \times 1.2 \mathrm{~m})$, the number of plants was counted and the fresh root yield was measured (dry root yield was calculated using lab data).

Data were processed statistically using software MS Office Excel 2007 (ANOVA: Single factor).

\section{Soil characteristics}

The soil belongs to the brown acid soils type (dystric cambisol), with the medium acidic reaction, rich humus supplies, low phosphorus content, and medium potassium supply in the topsoil (Tab. 1).

Climatic conditions during the experiment

Temperatures and precipitation during the experimental period are given in Figure 1 and Table 2.

Table 1. Chemical characteristics of the arable soil layer, $0-30 \mathrm{~cm}$

\begin{tabular}{lccccc}
\hline \multirow{2}{*}{ Locality } & $\mathrm{pH} / \mathrm{H}_{2} \mathrm{O}$ & $\mathrm{pH} / \mathrm{KCl}$ & & & \multicolumn{2}{c}{ (AL humus - method), Available mg/100 $\mathrm{g}$} \\
\cline { 5 - 6 } & & & & $\mathrm{P}_{2} \mathrm{O}_{5}$ & $\mathrm{~K}_{2} \mathrm{O}$ \\
\hline Kaluđerske bare & 5.8 & 4.6 & 4.0 & 4.7 & 13.8 \\
\hline
\end{tabular}

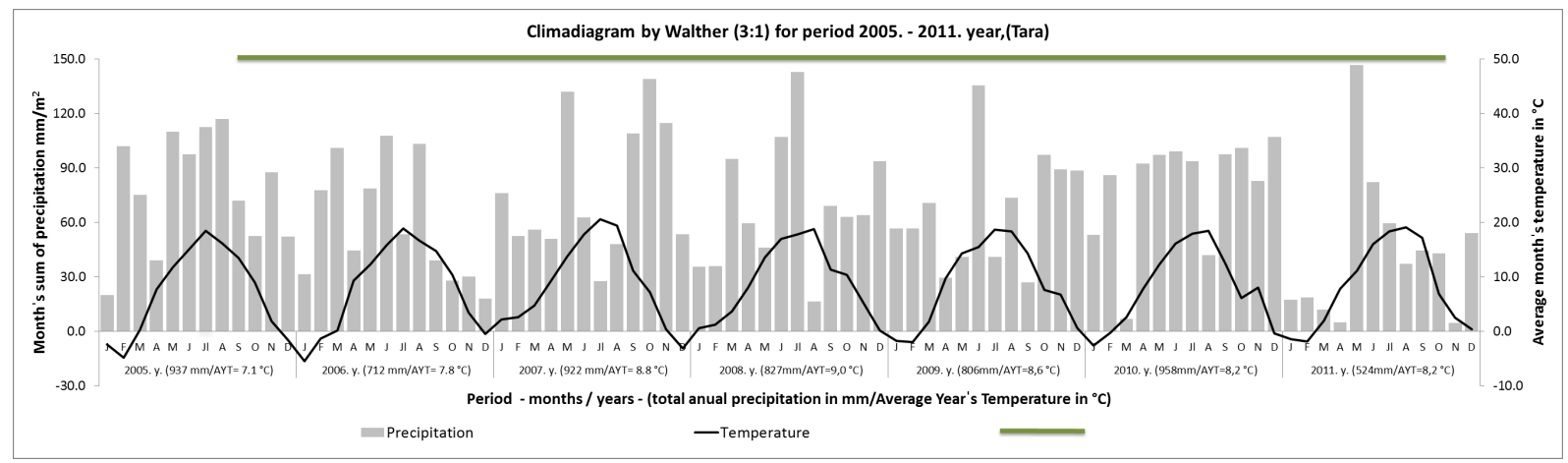

Figure 1. Climate diagram by Walther (3: 1) for the experimental period (2005-2011)

Table 2. Climate data for six vegetation periods (April - September) during the experiment

\begin{tabular}{lcccccc}
\hline & First year & Second year & Third year & Fourth year & Fifth year & Sixth year \\
\cline { 2 - 7 } & 2006 & 2007 & 2008 & 2009 & 2010 & 2011 \\
\cline { 2 - 7 } & 426.0 & 430.0 & 440.6 & 347.6 & 521.3 & 374.5 \\
Precipitation $(\mathrm{mm})$ & 14.6 & 15.3 & 14.4 & 15.1 & 14.2 & 14.9 \\
Average temperature $\left({ }^{\circ} \mathrm{C}\right)$ & & & &
\end{tabular}




\section{Results and Discussion}

The development of plantations during six seasons (2006-2011)

Climate conditions largely influence the development of yellow gentian plants in the initial years of cultivation (Bezzi \& Aiello 1993, Franz 2012, Radanović et al. 2006, 2014). Climate analysis shows that the first winter in the open beds $(2005 / 06)$ was very cold, with average air temperature in January $-5.5^{\circ} \mathrm{C}$, while the lowest temperatures during the last ten days of January reached $-27^{\circ} \mathrm{C}$. However, due to the $15 \mathrm{~cm}$ snow cover during the whole winter season, plants in beds managed to sustain the winter so that at the beginning of the first season (April), number of plants ranged from $84 \%$ in control and $96 \%$ under the $\mathrm{bPB}$ mulch film, in comparison to the number of initially planted ones (Tab. 3). Besides the snow cover, mulch films also had a positive effect on overwintering of yellow gentian nursery plants, given that the number of the lost ones was significantly lower comparing to control. The loss of plants grown under mulch after the first winter ranged $4-9 \%$, and it can be considered satisfactory if we take into account the first experiences in which initial losses of gentian plant populations sometimes exceeded 50\% (Bezzi \& Aiello 1993, Kušar \& Baričevič 2007)

Table 3. Density of yellow gentian plants in different treatments, expressed in percentages

\begin{tabular}{lccccccc}
\hline \multirow{2}{*}{ Treatments } & \multicolumn{2}{c}{ First year* } & Second year & Third year & Fourth year & Fifth year & Sixth year \\
\cline { 2 - 8 } & Apr. 2006 & Oct. 2006 & Oct. 2007 & Oct. 2008 & Oct. 2009 & Oct. 2010 & Oct. 2011 \\
\hline Control & 84.0 & 80.0 & 69.0 & 62.5 & 58.0 & 55.0 & 55.0 \\
Black PE film & 91.0 & 82.0 & 73.0 & 72.4 & 68.7 & 66.9 & 65.8 \\
Silver PE film & 93.0 & 84.0 & 76.0 & 76.0 & 73.8 & 71.6 & 70.3 \\
Black permeable & 96.0 & 93.0 & 90.0 & 90.0 & 88.0 & 87.0 & 84.0 \\
biodegradable (bPB) film & & & & & & &
\end{tabular}

* just in the first season (2006), crop density (\%) was determined at the beginning and the end of vegetation period

Control

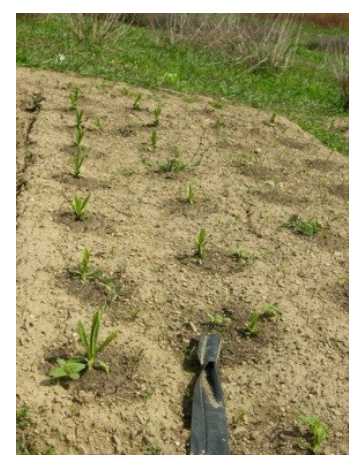

bPE film

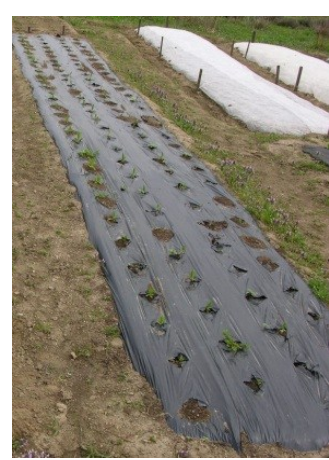

sPE film

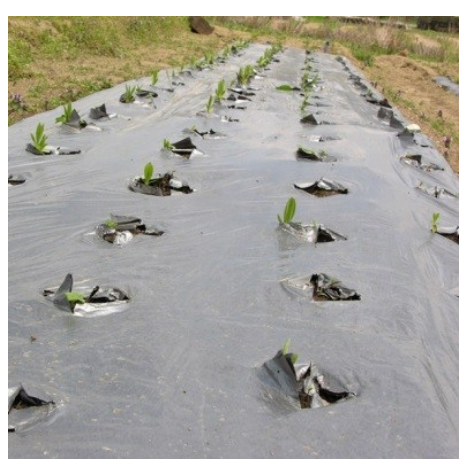

bPB film

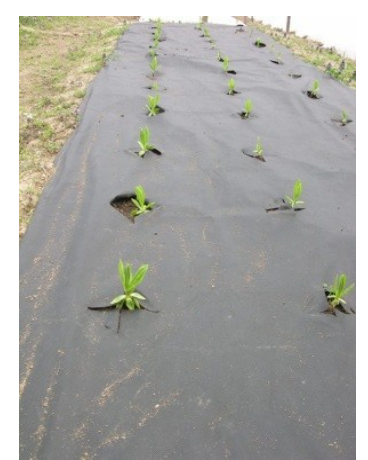

Photo 1. Yellow gentian plants grown on mulch films in the first season - 25 April 2006

Control

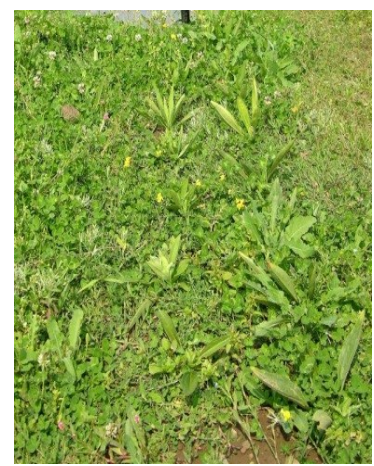

bPE film

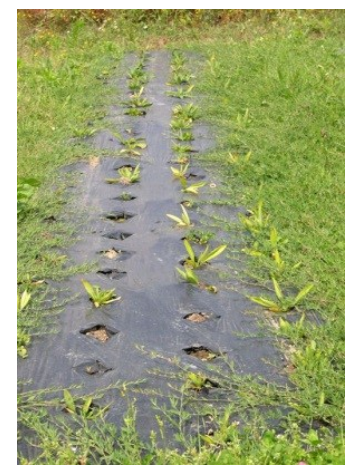

sPE film

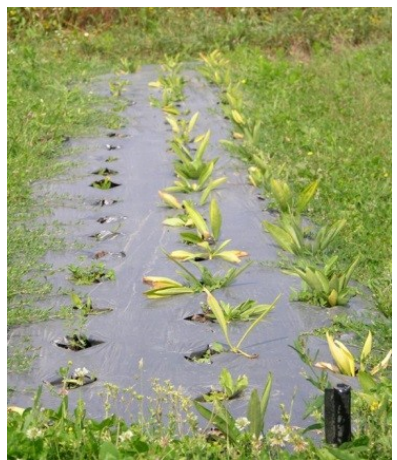

bPB film

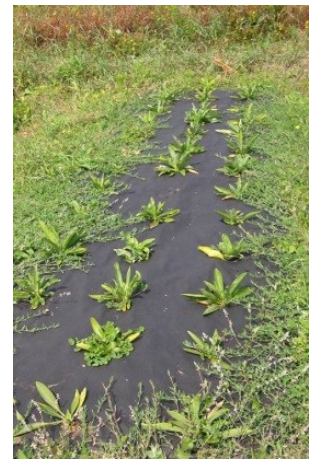

Photo 2. Yellow gentian plants grown on mulch films in the first season - 25 July 2006 
Plant decay in the first vegetation period occurred due to high summer temperatures, particularly under PE mulch films (Tab. 3); the highest recorded temperature was $30^{\circ} \mathrm{C}$ in the second half of June, last ten days of July, and at the beginning of August, when the temperature reached $32^{\circ} \mathrm{C}$. High insolation and heat in summer caused most damage to the lower leaves of plants grown under the bPE film, but significant damage also occurred on plants grown under the sPE film. Temperatures on the surface, especially under PE mulch films, were obviously too high for yellow gentian, and caused scorching in a significant number of plantles. In the first season scorching was lower under the bPB film and in control (Tab. 3, Photo 1 and 2).

The second season in 2007 was defined by extreme temperatures and drought. During summer, only $40 \mathrm{~mm}$ of rainfall was recorded in the course of 52 days (July 13 - September 2, 2007). Average air temperature in July was $23.3^{\circ} \mathrm{C}$, average daily air temperature $30.3^{\circ} \mathrm{C}$ over the course of 9 days (16-24 July), and average maximum daily air temperature was $35.3^{\circ} \mathrm{C}$, exceeding even $40^{\circ} \mathrm{C}$ for several days (Fig. 2).

Although yellow gentian plants were stronger in the second season, extreme heat caused significant damage in the form of scorch-necrosis on lower leaves of plants under PE mulch films. Some plants were completely scorched and decayed, causing additional decrease in crop density (Tab. 3). Density decrease also occurred in treatment with bPB film, though with the lowest damage (approx. 3\%). Control had the highest decay of yellow gentian plants in the second season, which was caused by weeds which, having been less affected by drought and heat, jeopardised the survival of the weaker yellow gentian plantlets (Tab. 3, Photo 4).

In the third season and the following seasons, when yellow gentian plants grew stronger, plant population did not significantly decrease under the effect of environmental factors. By the end of the sixth season crop density under bPE film additionally decreased by $7 \%$, resulting in $65.8 \%$ plants, under sPE film decreased by $6 \%$, resulting in $70.3 \%$ plants, whereas the bPB film resulted in $84 \%$ plants. The largest decrease in crop density during that period was recorded in control, with merely $55 \%$ of plants in the two final years (Tab. 3). Based on the aforementioned, it can be concluded that weeds caused higher crop density decrease in open beds without application of mulch films also during the later developmental stages of yellow gentian plants. During the initial years in which yellow gentian plants were small, most damage was caused by high summer temperatures, with deleterious effects on plants grown under PE mulch films, especially the bPE one. Plant population was best preserved until sixth season under the bPB film.

Occurrence of flowering stalks in yellow gentian plants grown on mulch films (generative stage)

First flowering stalks in yellow gentian plants appeared during the second season, while the largest number of plants with stalks was observed in the fifth and sixth seasons (Tab. 4). Plants grown on the bPB film already exhibited significant number of flowering stalks in the second year, and throughout all the following seasons they had the largest stalk number compared to other treatments. The first significant number of stalks in plants grown on both PE mulch films was recorded in the third year (about 7-8\%), with significant discrepancies in intensity in the following years. Complete absence of flowering stalks was observed in the fourth season, followed by the same intensity of the stalks incidence in the fifth as in the third season, and significant stalks incidence (ca. 30\%) in the sixth season.

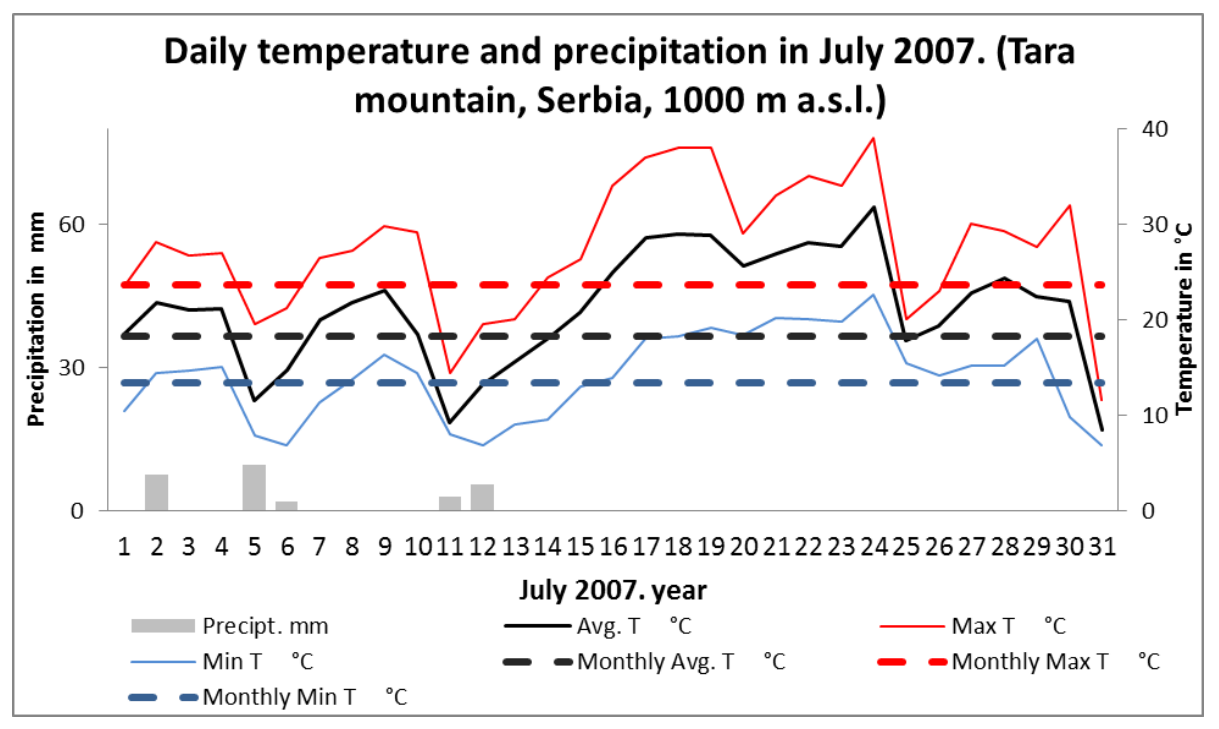

Figure 2. Daily temperatures and rainfall during 2007 on the experiment location 


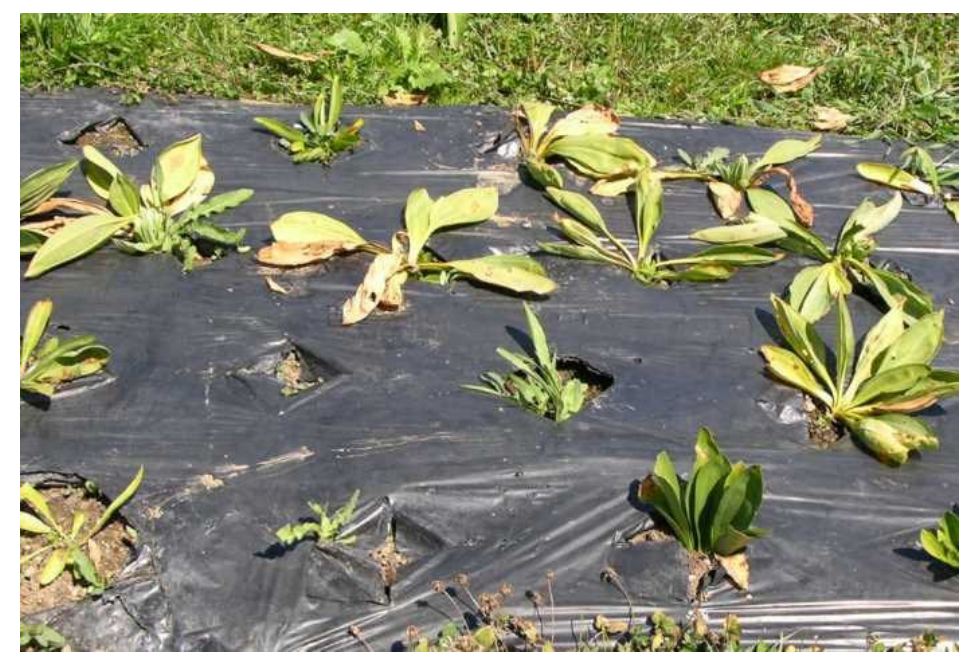

Photo 3. Damage to gentian plants on a black PE film in the second season - early August 2007
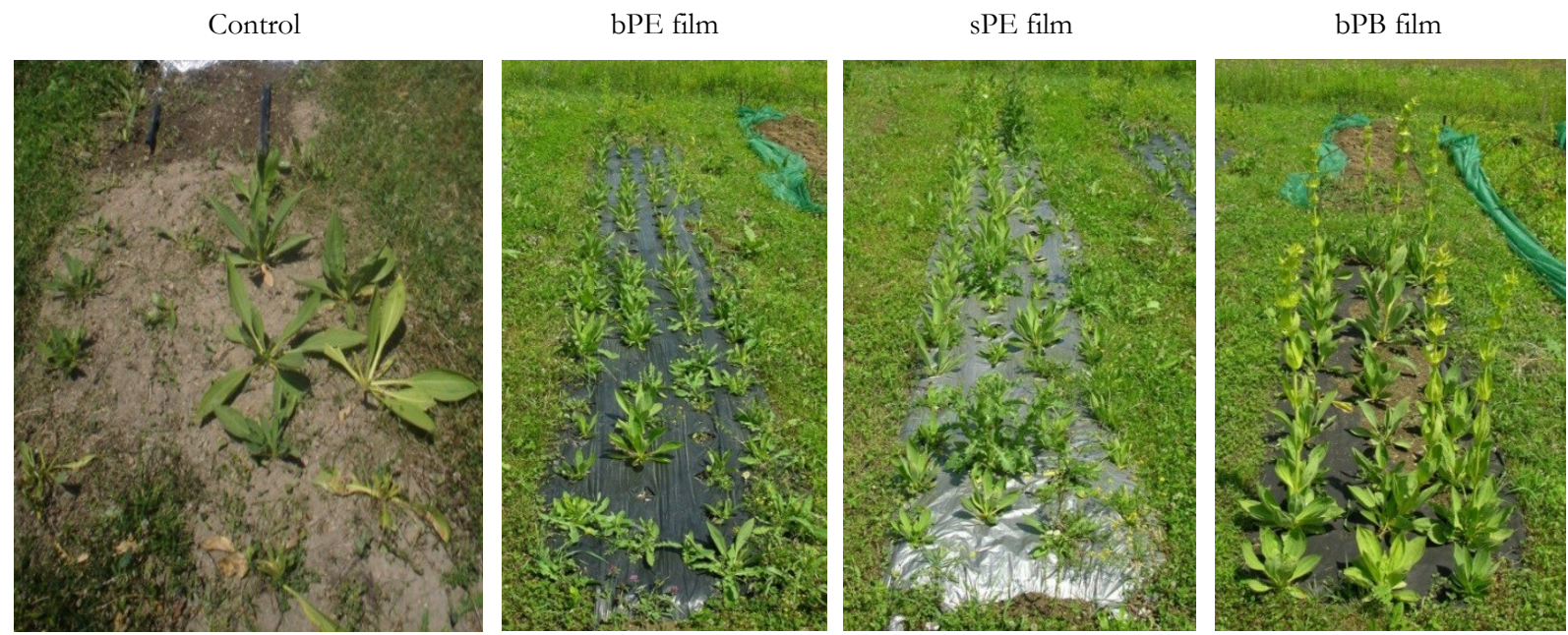

Photo 4. Yellow gentian plants grown on mulch films in the second season - 20 June 2007

The first appearance of flowering stalks in control (ca. $5 \%$ ) occurred in the third season, and in the following two seasons the percentage increased to $10 \%$ in the fifth, and $28 \%$ in the sixth one. Uneven number of plants with stalks on both PE mulch films (Tab. 4) leads to the conclusion that, besides mulch films, climatic factors also significantly affected the intensity of the flowering stalk incidence in yellow gentian plants. Low rainfall during April and May 2009 signals the possible cause of reduced formation of flowering stalks in yellow gentian plants, as observed by the same authors at other localities (unpublished data); however, this finding needs to be studied further.

\section{Root yield}

Yellow gentian root yields obtained under different treatments are shown in Tables 5 and 6, and in Figure 3.

Black permeable biodegradable mulch film (bPB

film). The largest individual root weight was observed under the bPB film in all seasons during the experiment, except in 2009 when average root weight was uniform on both PE mulch films and control (Tab. 5). This probably resulted from interaction of climate conditions, low rainfall and high temperatures in the fourth season (Tab. 2), as well as due to a larger number of plants per $\mathrm{m}^{2}$ compared to the sPE and bPE mulch films and the control. Due to the best preserved crop density, with favourable individual root weight of plants grown under the bPB mulch film, especially in the second half of the experiment, a drastic increase of root yield per $\mathrm{m}^{2}$ compared to the both $\mathrm{PE}$ films and the control was achieved during the fifth and sixth seasons (Fig. 3).

$P E$ mulch films (sPE and bPE films). During the initial growing period, bPE mulch film had a very low, even negative effect on the individual plant root weight compared to the control (Tab. 5). Due to significant loss of crop density, yield per $\mathrm{m}^{2}$ was lower and closer 
to control compared to the sPE and bPB films. Root yield of plants grown under bPE film increased during the second half of the growing period, from fourth to sixth seasons, exceeding control due to the better preserved crop density, while individual root weight per plant were similar to control in all seasons except in the fifth one. The sPE mulch film was more suitable than the bPE one, so the individual root weight and yield per $\mathrm{m}^{2}$ was significantly higher compared to control. Plants grown under the sPE film had a significantly higher yield per $\mathrm{m}^{2}$ compared to the ones grown under the bPE film, in all seasons, except in the fifth one. Individual root weight of plants grown under the sPE film was significantly higher than under the bPE one in the first half of the entire growing period (second to fourth year of cultivation), while it maintained the same in the second half, with increased yield per $\mathrm{m}^{2}$ (Tab. 6) due to the better preserved crop density. Compared to the bPB mulch film, individual root weight on the sPE film was similar in the first half of the growing period, later significantly decreasing in fifth and sixth seasons. Still, due to a significantly higher loss of crop density during the initial years, yield per $\mathrm{m}^{2}$ under the sPE film was significantly lower than in plants grown under the bPB mulch film during the entire period, except during the third season (Tab. 6).

Control. Individual yellow gentian root weights as well as the root yields per $\mathrm{m}^{2}$ in control treatment depended on weed development and climate conditions during particular growing stages. Significant plant decay and
$20 \%$ decrease of crop density observed in first season, followed by the additional decrease to $69 \%, 62.5 \%$ and $58 \%$ plants in the second, third and fourth seasons, respectively, resulted in higher average weight of individual plants in control than under bPE film in the first season, and identical weight of plants in control and under bPE mulch in the second, third, and fourth seasons. Control plants which survived with the lower density were individually stronger and, despite weed emergence, managed to achieve individual weight identical to plants grown under bPE mulch, where high summer temperatures decreased gentian plants growth. In the period that followed, individual weight of mature plants roots under bPE film in the fifth season was higher than in control (Tab. 5). Considering yield per $\mathrm{m}^{2}$, control and bPE film had the same yield during the first two growing seasons, whereas in the second half of the experiment (fourth, fifth, and sixth seasons) plants grown under bPE film had higher root yields. Unlike bPE film, control was inferior to the sPE one during the whole experiment, except in the second season, when individual root weights in these two treatments were identical (Tab. 5). Regarding yield per $\mathrm{m}^{2}$, significantly lower yield was observed in control than under sPE mulch film throughout the whole experiment, from the first to the sixth seasons (Tab. 6). Compared to bPB mulch film, plants set as control had lower individual root weights in all growing seasons except the fourth vegetation, as well as lower root yield per $\mathrm{m}^{2}$ throughout the entire experiment (Tab. 5 and 6).

Table 4. Occurrence of flowering stalks in yellow gentian plants grown at different mulch films

\begin{tabular}{lcccccc}
\hline \multirow{2}{*}{ Treatments } & \multicolumn{5}{c}{ Average number of plants with flowering stalks in relation to the total number of plants (\%) } \\
\cline { 2 - 7 } & First year & Second year & Third year & Fourth year & Fifth year & Sixth year \\
\cline { 2 - 7 } & 2006 & 2007 & 2008 & 2009 & 2010 & 2011 \\
\hline Control & 0 & 0 & 4.8 & 5.4 & 10.5 & 27.8 \\
bPE film & 0 & 0.8 & 8.7 & 0.0 & 7.0 & 30.1 \\
sPE film & 0 & 0.8 & 7.4 & 2.0 & 10.7 & 31.7 \\
bPB film & 0 & 19.3 & 19.1 & 18.5 & 23.5 & 38.9 \\
\hline
\end{tabular}

Table 5. The average root weights of individual yellow gentian plants in an experiment with different mulch films during the experimental period $(\mathrm{g})$.

\begin{tabular}{|c|c|c|c|c|c|}
\hline \multirow[b]{2}{*}{ Treatments } & \multicolumn{5}{|c|}{ The average weight of fresh yellow gentian roots $(\mathrm{g})$} \\
\hline & $\begin{array}{c}\text { Second year } \\
2007 \\
\end{array}$ & $\begin{array}{c}\text { Third year } \\
2008\end{array}$ & $\begin{array}{c}\text { Fourth year } \\
2009\end{array}$ & $\begin{array}{c}\text { Fifth year } \\
2010\end{array}$ & $\begin{array}{c}\text { Sixth year } \\
2011 \\
\end{array}$ \\
\hline Control & 63.7 & 167.5 & 305.0 & 345.0 & 502.5 \\
\hline bPE film & 49.0 & 166.1 & 316.0 & 439.0 & 550.0 \\
\hline sPE film & 75.0 & 236.5 & 355.0 & 452.0 & 626.7 \\
\hline bPB film & 109.0 & 213.5 & 328.0 & 620.0 & 887.2 \\
\hline $\operatorname{LSD} 5 \%$ & 12.44 & 22.74 & 35.39 & 49.42 & 78.80 \\
\hline $\operatorname{LSD} 1 \%$ & 17.14 & 31.33 & 48.76 & 68.10 & 108.57 \\
\hline
\end{tabular}


Table 6. The yields of fresh roots of yellow gentian grown on different mulch films during the experimental period $\left(\mathrm{g} / \mathrm{m}^{2}\right)$

\begin{tabular}{|c|c|c|c|c|c|}
\hline \multirow{2}{*}{ Treatments } & \multicolumn{5}{|c|}{ The average yield of fresh yellow gentian roots, $\mathrm{g}$ per $\mathrm{m}^{2}$} \\
\hline & $\begin{array}{c}\text { Second year } \\
2007\end{array}$ & $\begin{array}{c}\text { Third year } \\
2008\end{array}$ & $\begin{array}{c}\text { Fourth year } \\
2009\end{array}$ & $\begin{array}{c}\text { Fifth year } \\
2010\end{array}$ & $\begin{array}{c}\text { Sixth year } \\
2011\end{array}$ \\
\hline Control & 0.488 & 1.162 & 1.963 & 2.105 & 3.068 \\
\hline bPE film & 0.397 & 1.335 & 2.410 & 3.260 & 4.016 \\
\hline sPE film & 0.633 & 2.008 & 2.908 & 3.592 & 4.890 \\
\hline bPB film & 1.089 & 2.133 & 3.204 & 5.987 & 8.272 \\
\hline$L S D 5 \%$ & 0.115 & 0.191 & 0.296 & 0.378 & 0.676 \\
\hline $\operatorname{LSD} 1 \%$ & 0.158 & 0.263 & 0.408 & 0.521 & 0.931 \\
\hline
\end{tabular}

Analysis of the results obtained following application of different mulch films on yellow gentian when cultivated in agroecological conditions of Serbian mountains revealed that the efficacy of mulching, as a way of weed control, is dependent on the type of mulch film applied. The bPE mulch film provides the lowest positive effect compared to control, as a result of high temperatures which develop on and under this type of mulch, especially in summer. The same mulch showed favourable results on yellow gentian roots production in Finland (Galambosi 1996) but the intensity of insolation in Serbia is significantly different and, unlike in Finland, has potential harmful effects on young gentian plants. The use of sPE mulch film, considered ,cooler“ due to its reflective ability, could be a better solution for yellow gentian growth under Serbian agroecological conditions.
By the use of sPE film, plant population losses were lower than those under bPE, and generally higher root yield was achieved (Tab. 5 and 6). The use of plain drip tapes below both PE films is possible during the first and to a certain extent in the second season, while in the later seasons they did not prove functional. The bPB film, which is water-permeable, had the best effects on gentian root yield under agroecological conditions of Serbian mountains; large positive differences in root yield are especially detectable in the fifth and sixth seasons, reaching higher yields $92.3 \%$ and $106.0 \%$, respectively, than the bPE mulch, and $78.9 \%$ and $69.2 \%$ respectively, than the sPE mulch (Fig. 3 ). Yields of plants grown under the bPB film were higher $184.4 \%$ and $169.6 \%$, respectively, than in control.

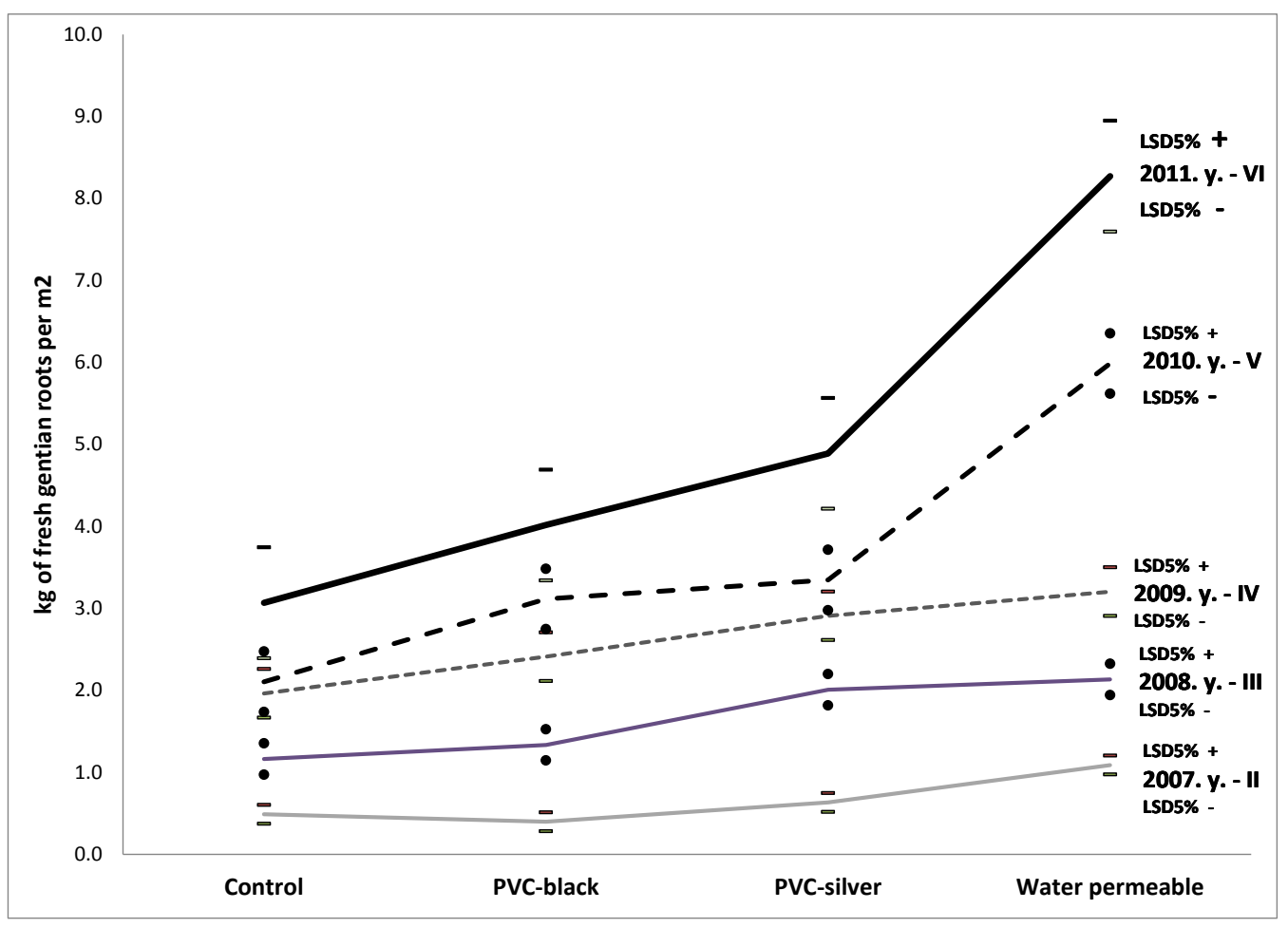

Figure 3. Yields of gentian root grown at different mulch films during a 5-year period 
Concerning durability of used mulch films, sPE and bPE mulch films remained intact throughout the sixyear period of use and performed highly successful weed combat. Weeds emerged only in mulch holes next to gentian plants, which can be easily removed manually. The bPB film, made of biodegradable material, stayed intact only during the first season and started to tear at the beginning of the second one (Photo 4); its remaining parts kept its mulching ability until the end of second season and completely lost its function by the end of the third one. Although the bulk of the mulch film had been destroyed by the fourth, fifth and sixth seasons, no significant emergence of weeds which could endanger gentian plants was observed, due to a spread of gentian plants over $60-70 \%$ of the open bed surface.

\section{Conclusions}

The obtained results show that mulch films are very efficient in combating weeds in yellow gentian grown in agroecological conditions of mountainous regions in Serbia; the best results are observed by using bPB film (water-permeable and biodegradable mulch film).

Achieved root yields of $6.0 \mathrm{~kg} / \mathrm{m}^{2}$ in the fifth, and $8.3 \mathrm{~kg} / \mathrm{m}^{2}$ in the sixth season, for yellow gentian plants grown under bPB film are considered quite satisfactory in production conditions of the mountainous region of Serbia. Further research should define the optimal yellow gentian crop density and fertilization manner in order to increase the root yields and to better utilize surface under the bPB mulch film.

The bPE mulch film can be considered inappropriate for use in yellow gentian root production in the mountainous region of Serbia. Since the sPE film proved to be more efficient in comparison to the bPE mulch film, it should be preferably applied at the northern terrain expositions of the mountainous regions in Serbia.

\section{References}

Bezzi, A., \& Aiello, N. (1993). The cultivation of Yellow Gentian (Gentiana lutea L.) on the pre-Alps and Apenninic Mountains: Results and Applications. WOCMAP I - Medicinal and Aromatic Plants Conference: part 3 of 4. Acta Horticulturae, 331: 19-25.

Franz, Ch. (2012). Enzian, Gelber (Gentiana lutea L.). In: Handbuch des Arznei- und Gewurz-pflanzenbaus, Band 4, Arznei- und Gewurzpflanzen A-K, Verein fur Arznei- und Gewurzpflanzen Saluplanta e.V. Bernburg, 375-385.

Galambosi, B. (1996). Experiences of cultivation Gentiana lutea L. in Finland. In: Atti del Convegno Genziana e specie amaroaromatiche. Ricerche ed Applicazioni. Camerino, 8-10 June 1995. L'uomo e l'ambiente 19: 139-142.

Kušar, A., \& Baričevič, D. (2007). Cultivation trials of yellow gentian (Gentiana lutea L. subsp. symphyandra Murb.) in west part of Slovenia. Acta Agriculturae Slovenica, 87: 213-222.

Momirović, N., Oljača, V. M., Dolijanović, Ž., \& Poštić, D. (2010). Energy efficiency of indoor pepper production using different types of PE foils (In Serbian). Poljoprivredna tebnika, 35(3): 1-13.

Radanović, D., Nastovski, T., Pljevljakušić, D., \& Jevđović, R. (2006). Growing results of some MAP species at mountainous region of Serbia. Proceedings 3rd Conference on MAP of Southeast European Countries, Nitra, Slovak Republic, 84-93.

Radanović, D., Markovic, T., \& Jankovic, T. (2007). Morphological and chemical parameters of importance for cultivation of Gentiana lutea L. in mountain region of Serbia. Proceedings $1^{\text {st }}$ Int. Sci. Conf. on Medicinal, Aromatic and Spice Plants. Nitra, Slovakia, 28-32.

Radanovic, D., Markovic, T., Aiello, N., \& Fusani, P. (2014).

Cultivation trials on Gentiana lutea L. in Southern and Southeastern Europe. Journal of Applied Research on Medicinal and Aromatic Plants, 1(4): 113-122.

RHMZ (2015). Hydro-meteorological Database for the Republic of Serbia. Retrieved from http://www.hidmet.gov.rs

Seitz, R., Lange D., \& Franz, C. (2005). Gelber Enzian - Porträt Einer Arzneipflanze, Zeitschrift für Phytotherapie, 26: 143-150.

\section{Efikasnost različitih malč folija u gajenju lincure (Gentiana lutea L.) u Srbiji}

\section{Dragoja Radanović · Tatjana Marković · Jovica Vasin · Dušana Banjac}

Sažetak: U poljskom ogledu na $1000 \mathrm{~m}$ n.v. ispitivana je efikasnost različitih malč folija na razvoj i prinos korena lincure u šestogodišnjem periodu. Gustina useva je bila 11,1 biljaka po $\mathrm{m}^{2}$ uz upotrebu crne i sive PE folije $\mathrm{i}$ crne vodopropusne biorazgradive folije. Najbolji sklop od $84 \% \mathrm{u}$ VI godini postignut je na vodopropusnoj foliji, kod crne PE folije broj biljaka se smanjio za 34,2\%, a na kontroli za 45\%. Prinos korena je bio najviši na vodopropusnoj foliji; viši od crne za 92,3\% (V vegetacija) i 106,0\% (VI vegetacija), viši od sive PE folije za 78,9\% (V) i 69,2\% (VI), viši od kontrole za 184,4\% (V) i 169,6\% (VI). Crna PE folija je postigla najniži pozitivan efekat u odnosu na kontrolu (od 18,6\% do 54,95\%). Na sivoj PE foliji je postignut bolji prinos od crne za 29,7\% i kontrole za 70,6\%.

Ključne reči: folija, Gentiana lutea, lincura, malč, prinos korena 